\title{
知的データキャリアによる群ロボットの機能創発
}

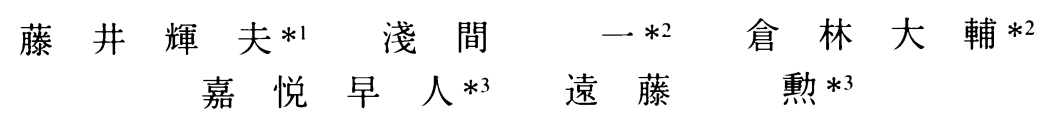

\section{Function Emergence in Multirobot Systems Utilizing Intelligent Data Carriers}

\author{
Teruo Fujii*1, Hajime Asama*2, Daisuke Kurabayashi*2, \\ Hayato Kaetsu*3 and Isao Endo*3
}

\begin{abstract}
This paper describes the use of the newly developed system named "Intelligent Data Carrier System: IDC System" to execute several tasks by a multirobot system in a so-called "emergent" manner. In order to realize the function emergence in real systems, it is important to consider how to design and embed the system into a real form, rather than theoretical or numerical researches on an emergent behavior itself. Based on the discussion on the design frameworks of an "emergent system", we try to implement the IDC system along with an actual multirobot system which consists of omnidirectional mobile robots equipped with folk lifts for handling of the IDC units. The applicability of the IDC system is demonstrated through the experiments for two kinds of tasks; 1) object transportation, and 2) patrolling. It can be concluded that the IDC system is effectively used in the tasks appearing in the practical missions of multirobot systems which can be regarded as one of the physical (real) systems that could realize "function emergence".
\end{abstract}

Key Words: Intelligent Data Carrier, Multirobot System, Function Emergence

\section{1.はじめに}

筆者らは, 創発的機能形成を具体的に実現する対象として, 複 数の移動ロボットによって構成される群ロボットシステムをとり あげ, 環境およびオペレータと相互作用しながら学習, 進化を通 じて作業目的や環境条件に応じた知的行動を獲得しうるような群 ロボットシステムの研究を進めてきた.実際に工学システムにお ける機能創発を考える場合，1）創発システムをどのようにとら えるか，どのように設計するかといった側面と，2）具体的な創 発メカニズムをソフトウェア,ハードウェアを含めてどのように 実現するかといった実装上の側面を同時に考慮する必要が

原稿受付 1998 年 6 月 4 日

" 東京大学生産技術研究所

$\because 2$ 理化学研究所工学基盤研究部

$\cdot 3$ 理化学研究所生化学システム研究室

${ }^{\cdot 1}$ Institute of Industrical Science. University of Tokyo

"2 Department of Research Fundamentals Technology, The Institute of Physical and Chemical Research (RIKEN)

${ }^{* 3}$ Biochemical Systems Laboratory, The Institute of Physical and Chemical Research (RIKEN)
ある[1].

創発システムの研究では, 状況が変化したり予測できなくて も，環境に適応した動作ができるような機能がどのような仕組 みになっているのか, どうすればそれを実現できるのか, が興 味の対象である[2]. ロボットを創発システムの具体的題材とし て議論する場合, その構造のどこまでを創発する部分と考える かによって，

1）レベル $1:$ 情報処理機構の創発

2) レベル $2:$ 制御システムも含めた創発

3）レベル 3:物理的機構も含めた創発

の三つのレベルを考えることができる[3]. 群ロボットシステム を考える場合, 例えばロボットのために整備した作業環境まで も含めたシステム全体を設計対象ととらえれば，以下のように 創発のレベルの解釈が可能である.すなわち, ロボットが参照 する標識や通信回線などを設置し, 群ロボット間でやりとりす る情報などについても，あらかじめ設計した上で，ロボットに どのような動作をさせればシステム全体として創発的にふるま うかという議論がレベル1である. また, 特定の情報に対して, ロボットが参照すべき標識や各種の通信や表示などの内容を固 定的なものとせずに, その物理的な配置のみをあらかじめ設計 
した上で，創発的な挙動を実現しようとすれば，これはレベル 2 にあたると考えられる.さらにインフラストラクチャの物理的な 配置や動作そのものも含めて，ロボットとの情報のやりとりに よって積極的に変更することまで考慮すれば,レベル3の創発を も含めたシステム構成を考えることができる.

本論文では,群ロボットシステムにおける機能創発を柔軟に行 うための具体的ハードウェアとして,ローカルな情報管理のため のデバイスである“知的データキャリア (Intelligent Data Carriers: IDCs)” [4] [5]導入し, 具体的作業への応用可能性に ついて検討を行う.はじめにIDCシステムの概要について述べ た後に, 群ロボットによる荷物搬送作業ならびに環境探索作業を 取り上げ, IDCを用いた機能創発の方法を示すと同時に実ロボッ トを用いた実験を通じてその実現可能性を検討する。

\section{IDC システムの開発}

群ロボットシステムにおけるロボット相互の情報のやり取りに ついては,何らかの通信手段を用いてブロードキャストによって 行う方法が普通であるが,この場合, システム内のロボットの数 が増えるに従って,グローバルな通信に必要な容量が膨大なもの となる。一般に群ロボットシステムのミッションにおいて高度に 知的な機能が必要となる局面は,ほとんどの場合特定の物や場所 などの局所的な状況であり，こうした局面に関する情報や経験に ついても局所的に蓄積されていれば十分である.例えば,プラン トのメインテナンスを想定するとき, 特定の機器のメインテナン ス履歴やその方法などの情報は, 各ロボットがそれぞれ持ち歩く よりは, その機器の周辺に置いておくことが望ましい.すなわち 局所的に情報を蓄えることができ,かつその場所に達したロボッ トがアクセス可能なデバイスを考えることにより,グローバルな 通信のための資源を圧迫することなく必要な情報をやりとりする ことができる.そのような局所的な情報の蓄積, 通信および処理 を行う具体的なデバイスとして筆者らはインテリジェントデー夕 キャリアの開発を進めている[3][4]. IDCはロボットによって持 ち運び可能なデータストレージであり, 局所的通信によってデー
夕を読み書きすることができるとともに，搭載しているCPUに よって内部で情報処理を行うことが可能なデバイスである.特定 の場所や物にIDCを取りつけることは，その場所や物をエー ジェント化することに対応しており，ロボットはIDCによって 作業エリアの情報環境を積極的に作り替えることができる.前章 での議論によれば，すなわちIDCを用いることにより，原理的 にはレベル 3 の創発が実現可能である。

\subsection{IDC システムの概要}

IDCシステムはFig.1に示すように，環境中に設置されるデバ イスであるIDCと局所的通信を行うためにロボットに搭載され るReader/Writer とからなる. IDC は環境内の場所や物に配置さ れ，電源節約のため通常は通信を行わない状態 (sleep mode) に なっており, Reader/Writerがある特定の通信可能範囲に入ると 通信が開始され，デー夕の読み出しおよび書き込みが可能とな る。なお現状では, Reader/Writerからの通信開始要求に対して 最初に応答したIDC との間にのみ通信が成立するいわゆるコン テンション方式を採用することによって, 複数のIDCが通信可 能範囲に存在する状況に対処している。

\subsection{IDC の構成と諸元}

IDC はFig.2に示すように，「無線通信部 (Communication Unit）」「情報処理部（Data Processing Unit）」および「電源部

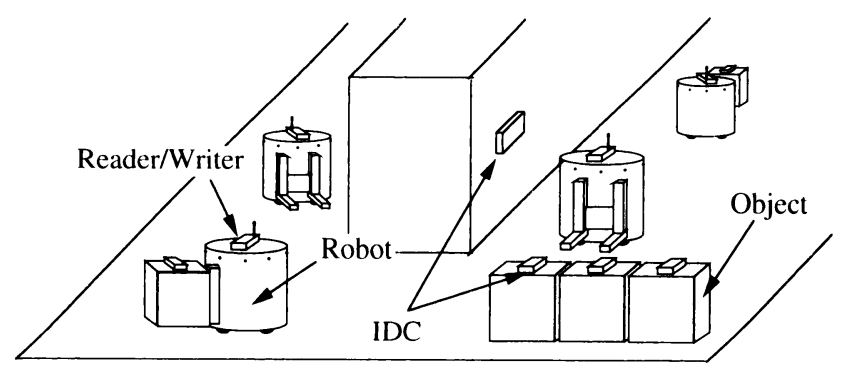

Fig.1 The concept of the IDC system

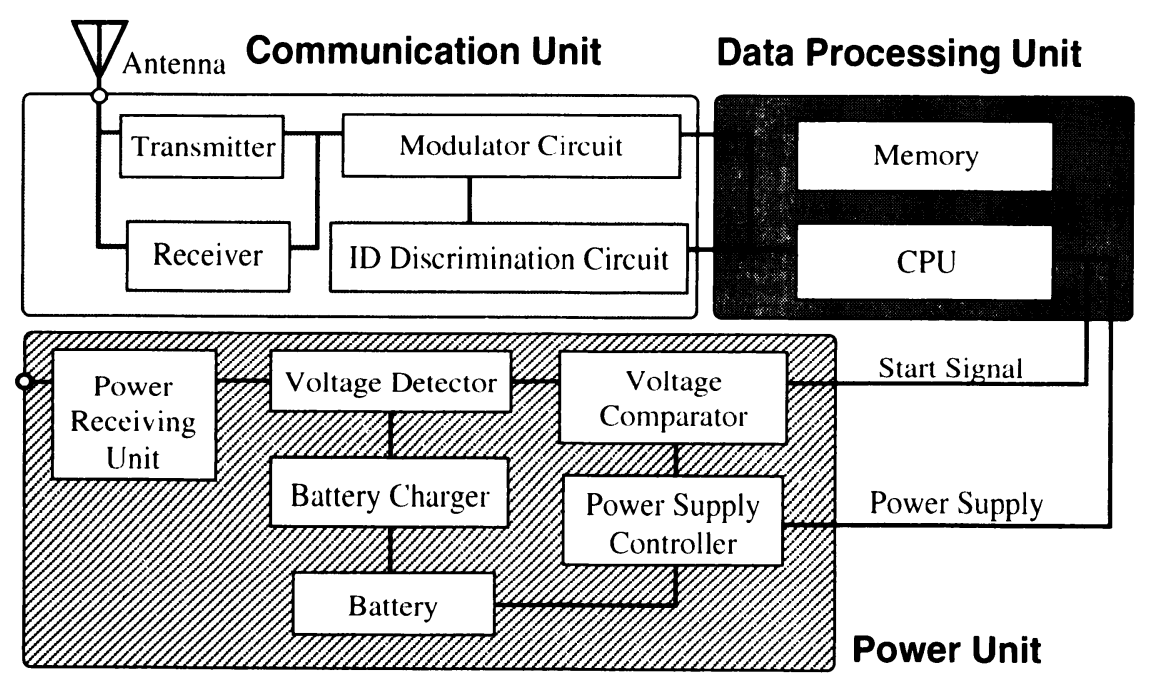

Fig.2 Schematic circuitry of the intelligent data carrier 
Table 1 Specifications of the IDC

\begin{tabular}{|l|l|}
\hline Media & Electromagnetic Wave \\
Frequency & $90 \mathrm{MHz}$ \\
Modulation & $\mathrm{FM}$ \\
Data Rate & $9600 \mathrm{bps}$ \\
Range & $1 \mathrm{~m}$ \\
Intensity & $<10 \mathrm{~mW}$ \\
Power Supply & DC5V \\
CPU & z80 class \\
Memory & 32 Kbyte \\
\hline
\end{tabular}

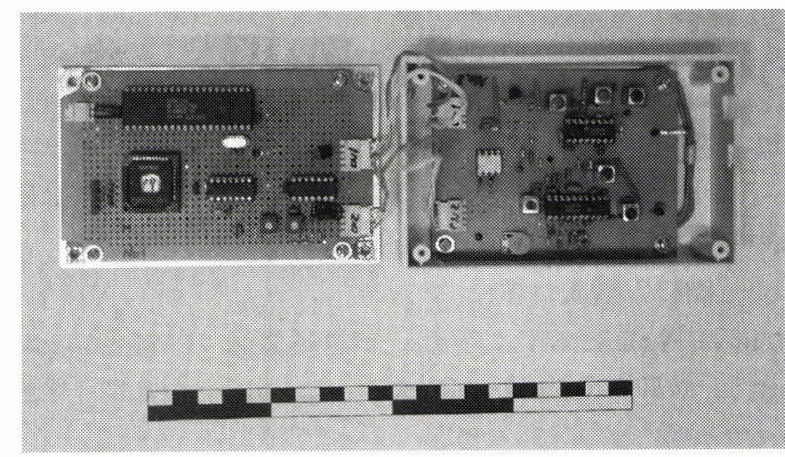

Fig.3 A prototype of the IDC

(Power Unit)」の三つの部分から構成される. 無線通信部は, FM 変調された電磁波を用いて,データの送受を行う。情報処理部は 受信したデー夕を解釈し, 情報をメモリに蓄積したり, 逆にメモ リから情報を取り出したりすると同時に, 特定のプログラムを実 行することによって, 新たな情報を作り出すこともできる.電源 部は, 太陽電池, あるいはロボットからの電磁放射などの非接触 手段により供給された電池を二次電池に蓄積する構成を最終目標 とするが, 現段階においては, 乾電池による駆動方法をとってい る。なお，ロボット側に装備するReader/Writerは, Fig.2の構成 から電源部分を取り外したもので, 電源供給と制御については口 ボット側から有線で行う. Table1に試作第一号機の諸元を, Fig.3 にその外観を示す.

\section{3 通信性能の確認}

ローカルに限定した通信が可能かどうかを検証するために， Reader/Writer とIDCとの間の距離を変化させながらデー夕送信 を行い, 受信成功率の変化を測定した，Fig.4の結果は，IDCの 八ウジングとなっている箱の長軸と, 同じくReader/Writerの箱 の長軸を揃えた上で, その間の距離を $0[\mathrm{~cm}]$ から $10[\mathrm{~cm}]$ おきに 徐々に遠ざけながら, 通信確立動作を各 100 回ずつ行い, その成 功率を記録したものである. その結果, $0[\mathrm{~m}]$ から $1[\mathrm{~m}]$ の間では 100\% 通信に成功しており，1.25[m]越えるあたりから急速に 成功率が低くなっている。これにより, 当初の目的である通信の 局所性が確認された。

2.4 IDC ユニットの製作

IDC を用いて具体的実験を行うためのプラットフォームとし

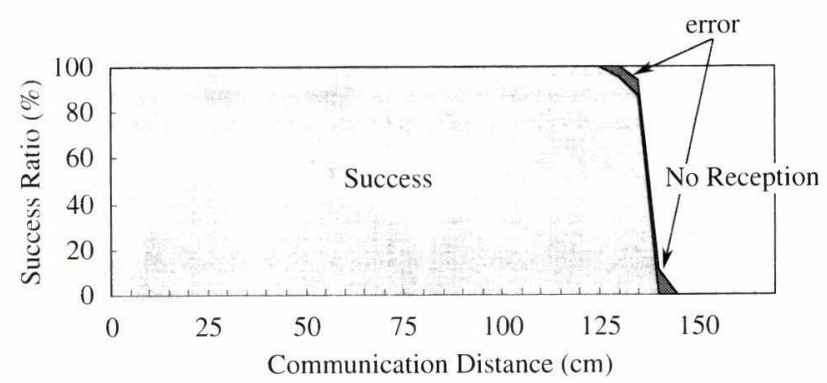

Fig.4 Communication characteristics of the IDC

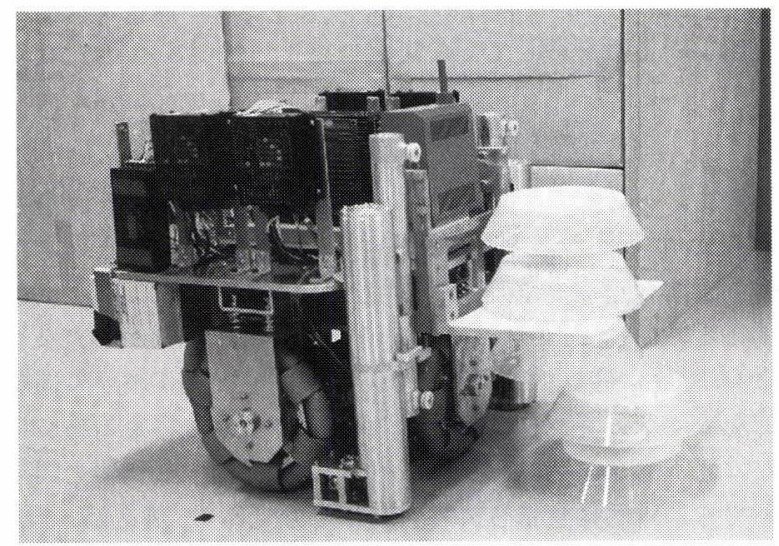

Fig.5 The omnidirectional mobile robot
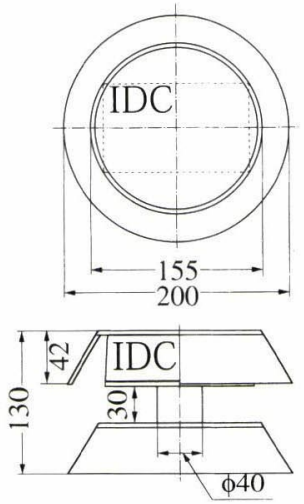

Fig.6 Design of the IDC unit

て, Fig.5に示すようなフォークリフトを搭載した全方向移動ロ ボット[6]からなる群ロボットシステムを考える。フォークに よって配置したり回収したりという作業が可能となるように， Fig.6に示すようなキノコ型のカバーをIDCに取りつけたものを IDCユニットと呼ぶ. キノコ型IDCユニットは, 上下二つの傘を 持つことにより，複数のユニットを重ねて運ぶことができる。 IDC は上の袢の内部に格納される。これにより，Fig.7に示すよ うにロボットがIDCを拾い上げたり，必要な場所に置いたりす ることが可能となる。すなわち，三つに重ねたIDC ユニットの うちの一つを床面上に置く際には，1）フォークをIDCユニット 


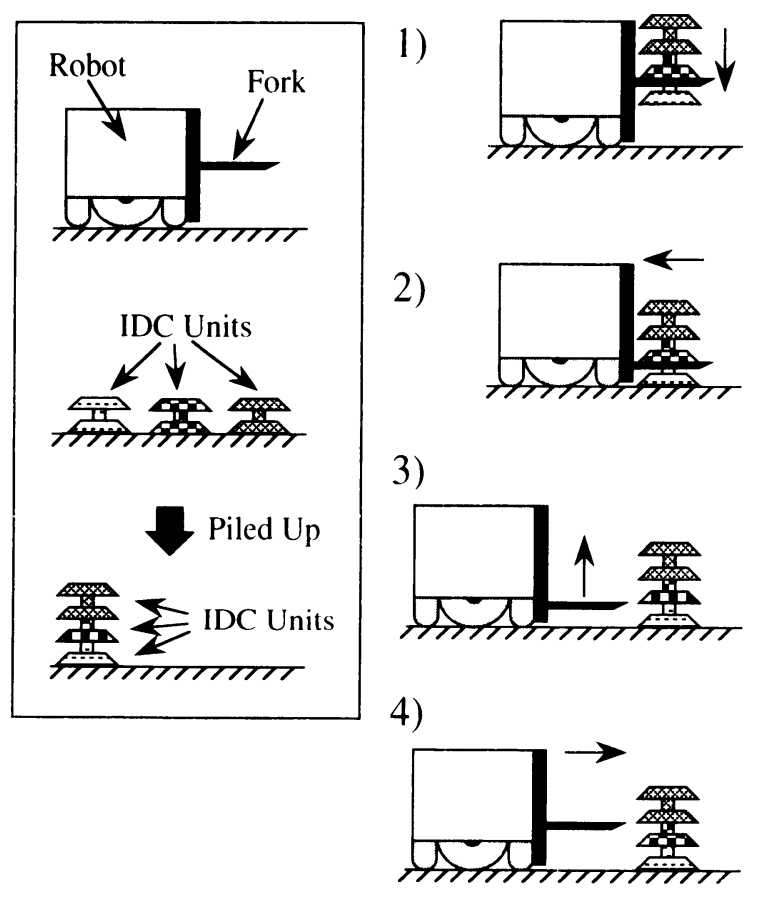

5)

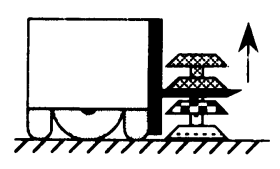

6)

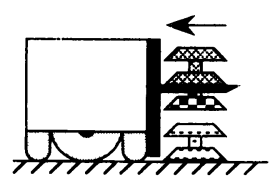

7)

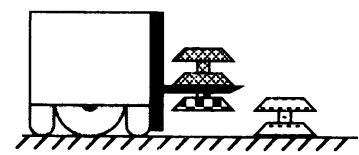

Fig.7 Handling method of the IDC units

が床面につくまで下げ，2）フォークをはずしてロボットが後退 し，3）フォークを持ち上げ，4）一つ上のユニットの徠の間に差 し込み，5）上の二つのIDC ユニットを持ち上げ，6）一番下の IDCユニットを残して，7）立ち去るという手順をとる。また, 床 に置かれたIDCユニットを回収する場合には，まず７）目的の IDCユニットに接近し, 6) 床面上のIDCユニットが手持ちのIDC ユニットに重なる位置まで前進し，5）フォークを下げて而者を 重ね，4）いったんフォークを引き抜き，3）フォークを一つ下の ユニットの来の位置まで下げ，2）ロボットが前進してフォーク を差し込み，1）フォークを持ち上げるという手順となる.

\section{IDCの実作業への適用}

群ロボットシステムにおけるIDCの具体的応用例として, 荷 物搬送作業, 環境探索作業を取り上げ,これらの作業において必 要となるローカルな情報をIDCに持たせることにより，効率良 く作業が行えることを示す.

\section{1 荷物搬送作業}

群ロボットによる協調作業の典型的な例として, 環境内に随時 運び込まれる荷物を目的位置へ運んで整理する作業が考えられ る.複数のロボットが並列分散的に搬送作業を行うことによって 効率が上がることが期待されるが, 荷物によって大きさや重量あ るいは目的位置が異なるケースを想定すると,あらかじめすべて の荷物に関する情報が各ロボットに与えられていないかぎり効率 よく作業を進めることができない.また，作業の途中で想定され ていない荷物が加わった場合には,これに対応することは困難で ある.このような問題に対し，Fig.1に示したIDCシステムの概 念によれば，荷物にIDCを載せ，その中に荷物の属性，目的位 置, 作業状況などの荷物固有の情報を書き込むことによって, 口 ボットはあらかじめ荷物に関する情報を与えられていなくとも， 作業対象とする荷物そのものから作業に必要な情報を得ることが できる.すなわち, IDCを用いることにより, ロボットは並列分 散的な動作が可能となり, また, 全体を統括しないにもかかわら ず, 群ロボットシステム全体としては, 荷物搬送作業という特定 の機能を実現（創発）しうる.

（1）荷物搬送のシナリオ

以上の議論をふまえ, 群ロボットによる荷物搬送作業に IDC を適用する際には, 以下のようなデー夕をIDCに書き込むこと が想定される。

1）荷物の ID

2) 現在位置

3) 目的位置

4）重量, 形状など荷物の属性デー夕

5）作業状況（搬送前／搬送済）

これらのデータを荷物に持たせれば,以下のような作業のシナリ オを考えることができる（Fig.8参照）.

1）ロボット（図中口）は作業環境内の巡回軌道に沿って, IDを 探しながら移動を続ける。

2）荷物（図中○）の近傍にさしかかると,IDCとの通信が接続 され，荷物に関する情報を読みとる。

3）荷物が搬送済みでなければ, 荷物の属性, 現在位置などを参 照して, 荷物を把持する。

4）目的位置データに従って，荷物を搬送する.

5）目的位置（図中○）に達したら，搬送済を示す情報をIDCに 書き込んで，再び巡回軌道に戻る。

（2）荷物搬送のシミュレーション

前節に述べたシナリオに従い, 複数のロボットによる荷物搬送 作業の実現可能性を確認するため, 計算機シミュレーションを 行った。その結果をFig.9に示す.Fig.9では 3 台のロボットA, B，Cがそれぞれ口で表される位置からスタート地点として巡回 軌道に沿って移動し，まず○で表される荷物 1 〜について，口 ボット A は荷物 1 を, ロボット $\mathrm{B}$ は荷物 2 をロボット C は荷物 3 


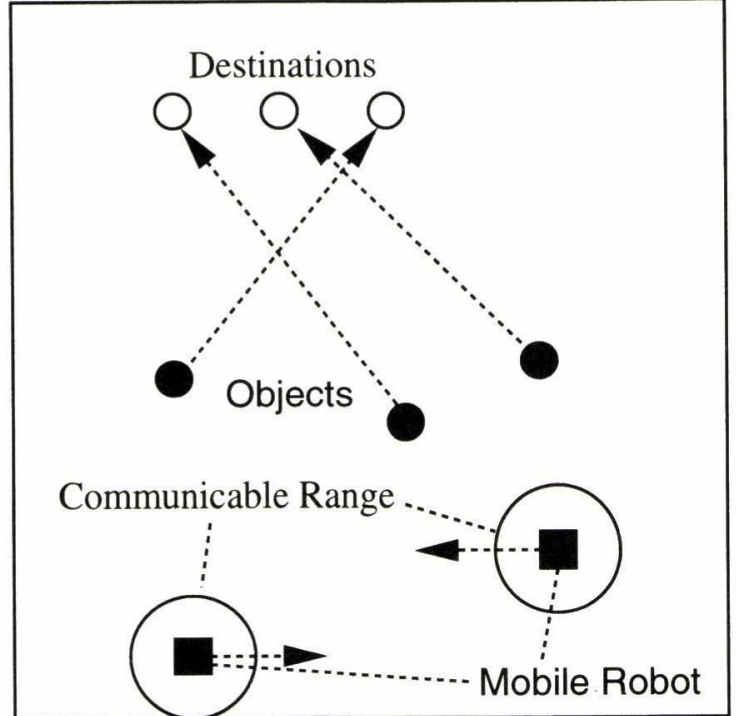

Fig.8 Object Transportation Task

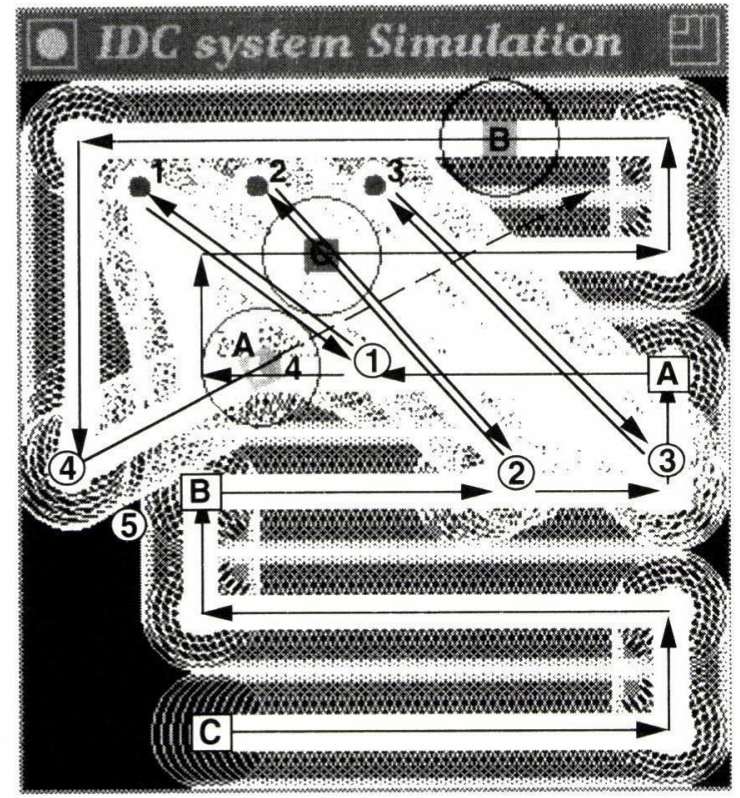

Fig.9 The results of numerical simulation

を発見して，目的位置まで搬送していることを示している.さら にロボットAは後から軌道上に置かれた荷物 4 を発見し, 目的位 置に向かうところである。以上により，IDCを用いれば，上に述 べたシナリオに従って,並列分散的に荷物が搬送できることが確 認された。

（3）荷物搬送の実験

さらに実環境において，ロボットがIDCから情報を読みとる ことによって荷物の搬送ができることを確かめるために, 全方向 移動ロボット[6]を用いて荷物搬送の実験を行った。その結果を Fig.10に示す．実験では, (a)まずロボットは $(0.0,0.0)$ の位置か

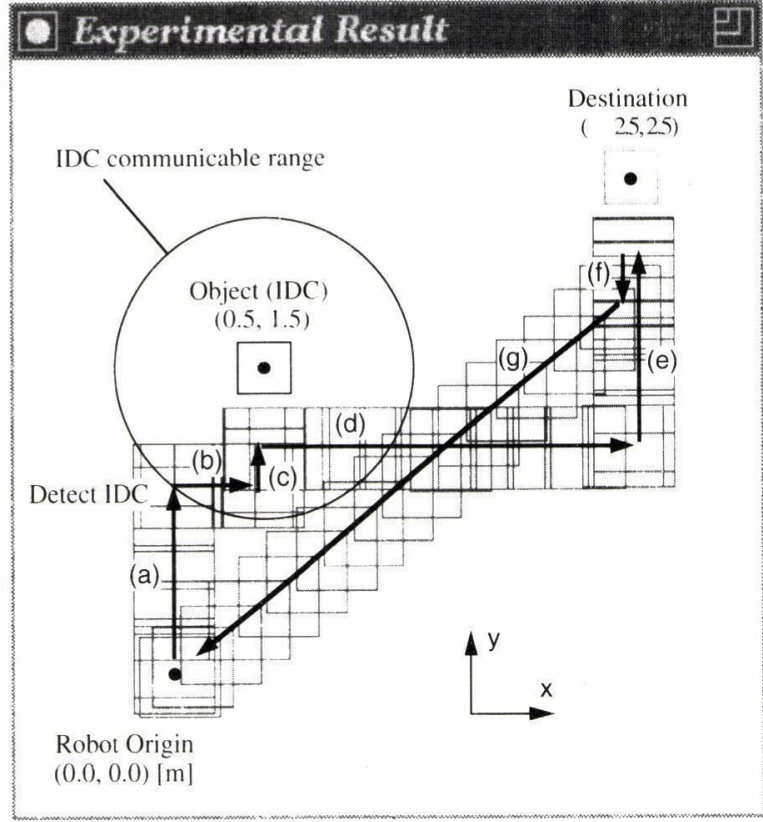

Fig.10 Experimental Results of Object Transportation

らスタートして巡回軌道上を $\mathrm{Y}$ 方向に進む。荷物に取り付けら れたIDCの通信可能範囲に入ると, IDCと通信を行い, その現在 位置を獲得して，アプローチする(b).ささらにフォークを荷物の 下に挿入して荷物を持ち上げ(c)，目的位置に向けてまずX方向 に(d)，次にY方向に(e)移動する。目的位置に到達すると荷物を 下ろしてからフォークを引き抜き(f)，元の軌道に戻る(g). 本実 験により，IDCに書き込まれた情報を使うことにより，以上のよ うな一連の荷物搬送動作が可能であることが確認された。

\section{2 環境探索作業への適用}

群ロボットシステムを用いたもう一つの作業例として, 屋内の 直行した廊下で構成される通路環境における探索作業を考える。 これは、ビル内の通路環境など人工的環境における巡回点検, 警 備作業への応用につながる作業例で, 複数のロボットが手分けし て, 環境内に変化がないかどうかを確かめながら, 効率よく全体 を網羅することが求められる。一般にこうした作業を行う場合， 環境全体のマップを中央で集中管理し，それぞれのロボットに配 布すると同時に, 作業中に各ロボットが獲得した最新情報をその マップに加えていく方法がとられる。この場合, すべてのロボッ トがマップを持ち歩く必要がある上に，情報が更新されるごと に，すべてのロボットにそれを伝えなければならず，通信に対す る負荷が非常に大きくなる。これに対して，環境内にIDCをあ らかじめ設置しておき，付近の情報をその中に蓄積する方法をと れば, 各ロボットは環境マップをすべて持ち歩くことなく, IDC から随時ローカルな情報を獲得することによって, 作業が遂行で きる。作業中に新たに獲得しうる情報は，一般に場所に依存した ローカルな情報であり，IDCに書き込むことによって，他の口 ボットにもその内容を伝えることが可能である.

(1) 環境探索作業のシナリオ

以上のような議論をふまえ，例えば Fig.11に示すような環境 内において複数のロボットによって探索作業を行うことを考え 
る。環境内の主要な分岐点にはIDCをあらかじめ設置するもの とし,IDCにはロボットに搭載されたセンサによって得られる情 報をもとに，以下のようなデー夕を蓄積する。

1) 分岐方向 (North, West, South, East)

2) 通路状態 (Path, Wall, Deadend)

3）探索作業状況（Not Yet, Searching, End）

各ロボットは分岐点に設置されているIDCを発見すると，その 中のデー夕を参照し, “Not Yet”の作業状況となっている方向が あれば，その方向に進む。“Not Yet”の状況が一つもない場合に は, “Searching”の方向に進むものとする。また, “Not Yet”の方 向が二つ以上あるときには, 例えば反時計回りの順番で, 進む方 向を決定すればよい.IDCに書き込まれたわずかな情報と簡単な アルゴリズムを用いるだけで, 複数のロボットによって環境内を 効率よく探索することができる.すなわち,この例についても荷 物搬送作業と同様, IDCを用いることにより, 各ロボットは並列

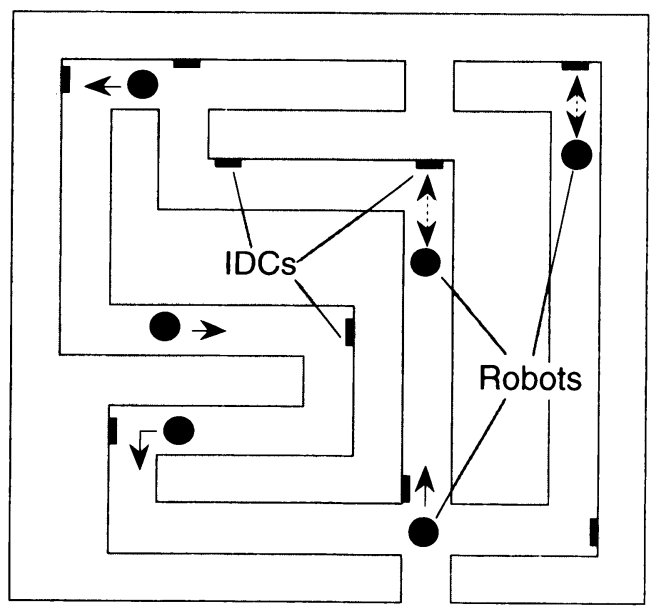

Fig.11 Patrolling Task in the Corridor Environment
分散的に動作することができるようになり，また，全体を統括し ないにもかかわらず, 群ロボットシステム全体としては, 環境探 索という特定の機能を実現（創発）することが可能である.

\section{(2) 環境探索の実験}

以上のようなシナリオに基づいて，ロボットがIDC との間で 情報を読み書きすることによって環境探索作業ができることを確 かめるために，前節と同様に全方向移動ロボット[6]を用いた環 境探索の実験を行った。実験では, Fig.12に示すような環境を想 定し, 人口 (Entrance) から複数のロボットが順次環境内に進入 し, IDCの情報に基づいて, 環境内を移動し出口（Exit）から出 るという過程を繰り返し, 最終的に環境内の全通路をロボットが くまなく通過することを目的とする.ロボットは障害物の有無を 検知するための赤外線七ンサシステム（LOCISS）[7]を搭載して おり，各分岐方向の通路状態を知ることができる。実験の結果 は, Fig.13に示すように，まず1台目のロボットが環境内に入り， NおよびSの方向について, Wall とPathであることを確認し, そ

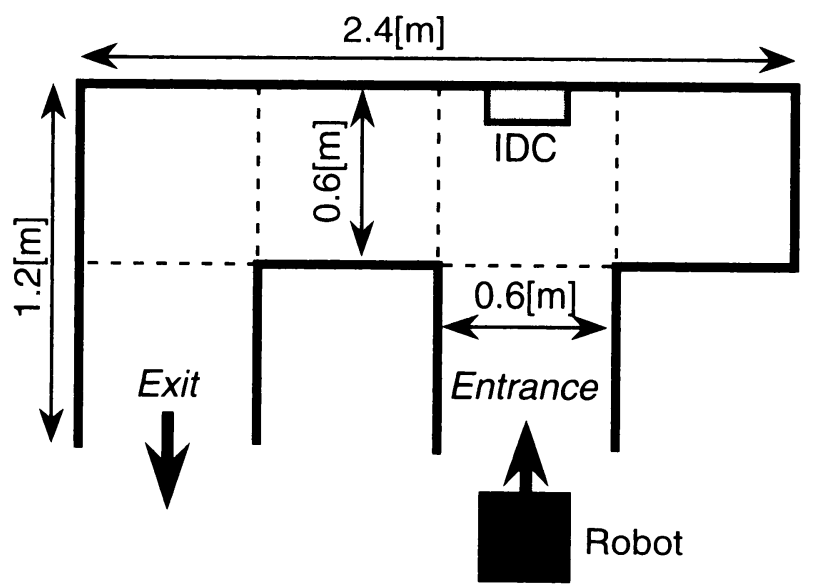

Fig.12 The experimental setup for patrolling tasks

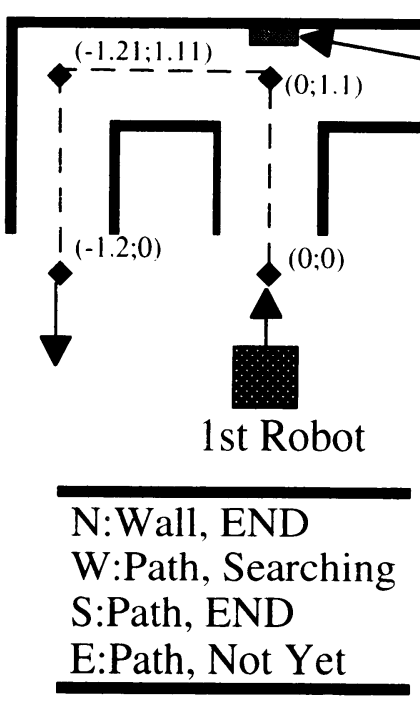

(a)
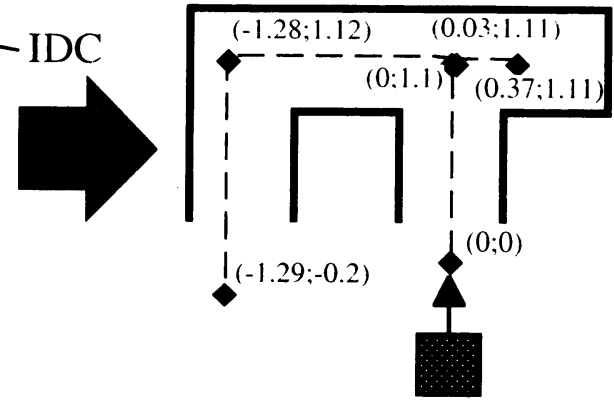

2nd Robot

$\mathrm{N}:$ Wall, END

W:Path, Searching

S:Path, END

E:Deadend, END

(b)
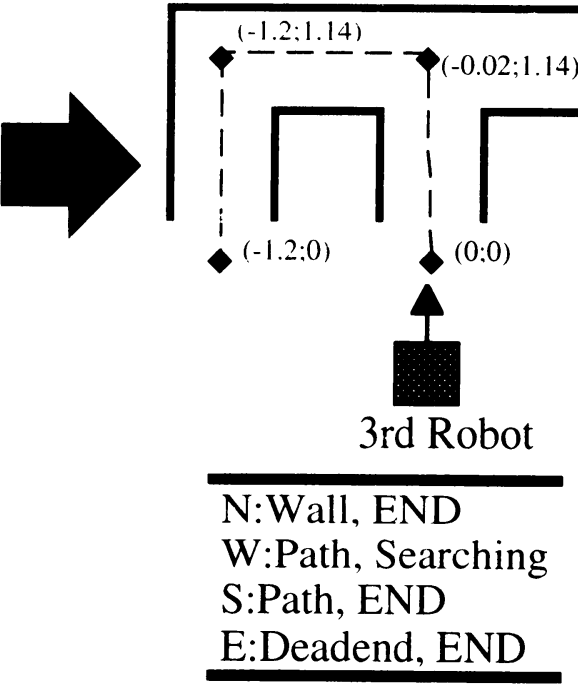

(c)

Fig.13 Experimental results of patrolling task in the corridor environment 
の情報をIDCに書き込む（Fig.13 (a)）．2台目のロボットは，進 入後IDCの情報に基づいて, “Not Yet”の作業状態になっている E方向へ進み, Deadendであることを発見して, これをIDCに書 き込む (Fig.13 (b)). 3台目以後のロボットはIDCに書き込まれ たE方向の情報を考虑して, 作業状況がSearching となっている W方向へ進むことになる $($ Fig.13 (c)). 以上のように, ロボット が新たに発見した情報をIDCに書き込んだり，IDCから読み出 した情報を使うことにより,一連の環境探索作業の実行が可能で あることが確認された。

\section{4.おわりに}

本稿では, 群ロボットシステムおいてローカルな情報からシス テム全体としての機能を創発するための具体的デバイスとして, インテリジェントデータキャリア（IDC）について述べ，その実 作業への応用について議論した。具体的作業事例として, 荷物搬 送作業および環境探索作業を取り上げ,実験によってそれらの機 能創発が可能であることを確認した。これらの事例はいずれも， いわゆる「創発システム」[2]を，あらかじめ明示的に意識してイ ンプリメントしたたものではないが, システム全体を創発的なも のとするためには (レベル3), 少なくとも「モノ」として構造 を変えることができるような物理的実体を意識することが必要で
ある、本論文における議論によれば，IDCを応用した群ロボット システムは,そのような物理的実体の実現形態として有望なシス テムの一つであると考えられる。

最後に, 本研究の機会を与えていたたいた文部省科学研究費補 助金重点領域研究「創発システム」関係各位に深甚なる感謝の意 を表す.

\section{参 考 文 献}

[1]藤井輝夫, 淺間一: “群ロボットシステムにおける創発の奏現”, 計測と制 御, vol.35-7, pp.545-548, 1996

[2]創発システム公開シンポジウム資料, 長津田, 1997.

[3] 淺間一, 藤井輝夫: “ロボットの創発性に関する一考察”, 第 3 回創発シス テムシンポジウム資料, 諏訪, pp.29-40, 1997.

[4] H. Asama, et al.: "Distributed Task Processing by a Multiple Autonomous Robot System using an Intelligent Data Carrier System," Proc. WAC 96, Volume 3, TSI Press Series, pp.23-28, 1996.

[5] T. Fujii, et al.: "Intelligent Data Carrier System for Cooperative Behaviors Emerged among Collective Robots," Proc. IEEE SMC'97, Orlando FL, pp.299-304, 1997.

[6] H.Asama, et al.: "Mutual Transportation of Cooperative Mobile Robots Using Forklift Mechanisms," Proc. IEEE Int. Conf. Robotics and Automation '96, Minneapolis MN, pp. 1754-1759, 1996.

[7] S. Suzuki, et al.: "An Infra-Red Sensory System with Local Communication for Cooperative Multiple Mobile Robots," Proc. IROS'95, Pittsburgh, PA, pp.20912096, 1995

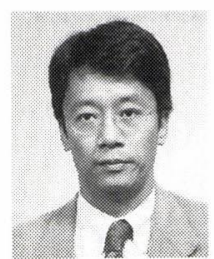

藤井輝夫 (Teruo Fujii)

1964 年 4 月 5 日生. 1988 年東京大学工学部船舶工 学科卒業. 1991 年 $\sim 1993$ 年日本学術振興会特別研 究員. 1993 年東京大学大学院博士課程修了, 博士 (工学). 同年, 東京大学生産技術研究所客員助教 授. 1994 年同助教授, 1995 年より理化学研究所生 化学システム研究室勤務, 1999 年より東京大学生 産技術研究所海中工学研究センター助教授. 生化学㧍よび生物学のた めのマイクロシステム, 自律分散型ロボットシステム, モジュラー型 ロボットの研究開発に従事. AAAS, INNS, IEEE, 日本生物物理学 会, 日本造船学会などの会員。 (日本ロボット学会正会員)

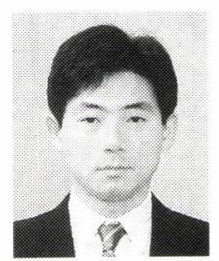

倉林大輔 (Daisuke Kurabayashi)

1970 年 9 月 15 日生. 1998 年東京大学大学院工学系 研究科精密機械工学専攻博士課程修了. 現在, 理 化学研究所研究基盤技術部基礎科学特別研究員. マルチエージェント・ロボットシステムの協調作 業の研究に従事. 博士 (工学). 精密工学会, IEEE の会員.

(日本ロボット学会正会員)

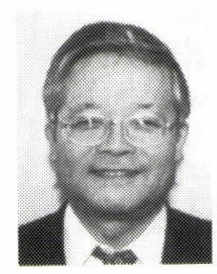

\section{遠藤 勲 (Isao Endo)}

1940 年 8 月 14 日生. 1970 年東京大学工学研究科博 士課程修了. 理化学研究所化学:工学研究室勤務, 現 在, 同主任研究員. 1989年より埼玉大学理工学研究 科客員教授兼任. 生物工学, 特にバイオプロセス工 ンジニアリングの研究に従事, 1978 年化学工学協 会論文賞受賞，1994 年ヘルシンキ工科大学名誉工 学博士, 1999 年化学工学会学会賞受賞. ニューヨーク科学アカデ ミ一, アメリカ化学工学会, アメリカ化学会, 化学工学会などの会 員.

(日本ロボット学会正会員)

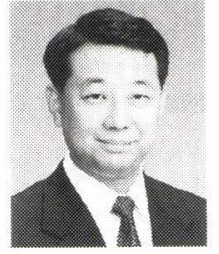

淺間 - (Hajime Asama)

1959 年 1 月 18 日生. 1984 年東京大学大学院工学系 研究科修士課程修了. 1986 年理化学研究所化学工 学研究室研究員補, 生化学システム研究室研究員, 先任研究員を経て, 現在工学基盤研究部副主任研 究員. 1999 年埼玉大学大学院理工学研究科客員助 教授. 自律分散型ロボットシステム, 複数移動ロ ボットの協調, 群知能, ロボットによる保全技術, バイオプロセスの 知能化技術の開発に従事. 1995 年日本機械学会ロボメック賞, 1996 年日本機械学会ロボメカ講演会Best Poster賞, RoboCup-98 Japan Open 人工知能学会賞(UTTORI United Team)等受賞. 工学博士 (東京大学). Distributed Autonomous Robotic Systems(Springer-Verlag)の第 1， 2 巻 の編者. IEEE, ニューヨーク科学アカデミー, 日本機械学会, 精密 工学会などの会員.

(日本ロボット学会正会員)

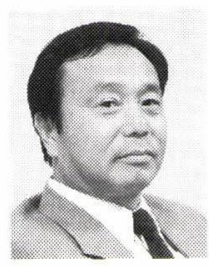

嘉悦早人 (Hayato Kaetsu)

1948年10月30日生. 1971年東京理科大学中退. 1971 年理化学研究所同位元素研究室勤務, 1981 年同化 学工学研究室へ移籍. 同位体分離, 分散型ロボット システムの研究に従事, 専任技師として現在に至 る. 日本原子力学会, 日本機械学会, 精密工学会の 会員. 